\title{
READING POLITICAL INSINUATION IN URBAN FORMS: SAVING THE SINKING JAKARTA THROUGH GIANT SEA WALL PROJECT
}

\author{
Eka PERMANASARI ${ }^{1}$
}

DOI: $10.21163 / G T \_2019.141 .19$

\begin{abstract}
:
This research examines the Giant Sea Wall project in Jakarta and how it symbolizes new postcolonial identity for Indonesia. As political insinuation in architecture and urban design is a common practice in postcolonial cities, power and legitimacy are shown through urban built forms. Considering that Jakarta has been constantly flooded, several attempts were installed, for instance building dikes along the coastline and making the east-west canals. However, this cannot stop the sea flood, as the severe land subsidence in the northern part of Jakarta grows rapidly. Giant Sea Wall aimed to protect the city from the flood later was transformed as a new symbol for Indonesia. However, as the project continues, the Indonesian politicians have asked the Dutch counterparts to redesign the Giant Sea Wall. The new design is no longer perceived as only the wall with small reclamation land, but rather as a new city shaped as Giant Garuda spreading from the east to the west part of Jakarta. The new postcolonial icon ironically was designed by the former colonial ruler. The research will explore the design and symbolism of the Giant Sea Wall project in order to understand the practices of urban design in the postcolonial city.
\end{abstract}

Key-words: Urban Design, Politics in Architecture, Southeast Asian Study, Post Colonialism.

\section{INTRODUCTION}

Jakarta's main problem is severe flood and increasing land subsidence. The city has long been suffering from both the upstream and sea flood. The land subsidence is mainly due to the massive extraction of ground water. Approximately, Jakarta is sinking between $0.5 \mathrm{~cm}$ to $15 \mathrm{~cm}$ per year. In fact, on particular areas, the land subsidence may reach up to $17 \mathrm{~cm}$ per year. (Public Works, Jakarta Coastal Strategy: ATLAS, 2011).

In addition, Jakarta is a delta of 13 rivers discharging to the Jakarta bay. However, since nearly $40 \%$ of the northern part of Jakarta is below the sea level, during the rainy season, Jakarta is a melting pot for seawater and uphill water (Public Works, Jakarta Coastal Defense Strategy: Agenda, 2011).

The floods, both from upstream and downstream, have often paralyzed the city. During the flood, there will be no electricity for days. Roads will be blocked and economy will disrupted for days. In addition, the flood itself often takes casualties (Korban jiwa akibat banjir Jakarta 19 orang, 2013). Apart from the flood, Jakarta also faces massive population growth yet lack supported by the infrastructure. It is a mega city without proper backbone on roads, public transport and proper city planning.

\footnotetext{
${ }^{1}$ Universitas Pembangunan Jaya. Indonesia. Eka.permanasari@upj.ac.id.
} 


\section{STUDY AREA AND DATA}

Jakarta is a growing city which has been the center for the urban development in Indonesia. Based on the PwC 2013 report, Indonesia is predicted to be a new emerging market economy (E7) based on PwC's report 'World in 2050' (PwC, 2013). As a capital city, Jakarta houses Capitol which determined both political and economic policy. Jakarta means business for many and central for political actions. As a postcolonial city, Jakarta houses several layers of political manifestation in architecture. From the Old Town Batavia to the Uptown Batavia, Jakarta has shown that the new nation was able to show national identity through architecture and urban forms (Kusno, 2000; Permanasari, 2010). The development of infrastructure in the city was also to respond the population growth and the rise of middle class Indonesia. Based on the World Bank report, the monthly expenditure of Indonesian people have increased with the significant peak at the middle class incomers (Chauduri, 2012). The rise of middle class will affect the national buying power.

One of the steadily growing businesses is the automotive industry. A minimum of 10 $\%$ rise of production on cars every year steadily in line with the population growth. However, while the buying power increases, and many people could afford to buys cars, the road development ratio is only $0.01 \%$ per year in Jakarta (Syarif, 2013). Train, BRT and MRT systems have been developed for the past few years but still unable to serve the commuting needs. The flight industry has also changed with low cost carriers providers emerged rapidly enabling people to fly across the archipelago easily. The development of airport, train, BRT and MRT networks could not catch up with the new emerging lifestyle. Romania is situated in the south-eastern part of Europe, its territory comprises 238391 $\mathrm{km}^{2}$ and its population reached 19760314 inhabitants in 2016 (Eurostat Database, 2017).

As the result, the number of cars on the road rises significantly and traffic jam is a common phenomenon. Jakarta suffers at least IDR 67000000000 lost per year due to the traffic (Sari, 2017). The city infrastructure is overwhelmed by the rapid growing economy. While MRT is still underway, public transport is heavily loaded on the inner-city train lines and 12 BRT corridors. This simply does not meet the requirement to serve the city's dynamic population with 13 million of people during the day and 10 million of people during the night. Jakarta constantly faces serious problem from sinking and poor transportation system.

To respond such situation, there are few attempts to rescue Jakarta. However, most of the proposed solutions only aimed to solve the problem partially. For instance, the river naturalization program was aimed to deepen the shallowing rivers due to the waste and clearing out the river banks. However, this program is often slower than the returning waste to the river. Apart from the river naturalization program, the government also builds two water tunnels (east and west canals) to divert the flood straight to the ocean. However, this program also faces difficulties when clogged drainage system in Jakarta makes this plan unsuccessful.

\section{METHODOLOGY}

This research uses discourse analysis to decode the layers of significations on the masterplan of the Giant Sea Wall. Discourse analysis is a complex method which does not fit regular definition of quantitative or qualitative methodology. The main discourse method is to decode the construction of meaning in relation to context. Unlike discourse analysis 
applied in linguistics, archival materials, built forms, cultural artefacts and spatial practices are considered as 'texts' for decoding (Fairclough, 2003).

The way in which discourse analysis works is through deconstruction. It defers any true meaning, but rather exposes multiple meanings (Fairclough, 2003). Thus, discourse analysis does not seek a final answer, but gives understanding as to how meaning is created, recreated, transformed and obstructed. This method will help us to understand the layers of political insinuation in architecture and urban built forms. The process of analysis includes coding the data. The open coding system allows us to interpret the collected data and label them based on the similar themes (Neumann, 2006). Based on this method, the data on the Giant Sea Wall design from 2014 until 2018 is analyzed. This allows to see on how the political insinuation in architecture and urban forms transform the city.

\section{RESULTS AND DISCUSSIONS}

The Giant Sea Wall project was initiated through joint cooperation between the Indonesian Government and the Dutch Government. Under the National Development Planning Ministry (Bappenas), the both parties issued a report of Jakarta Coastal Defense Strategy (JCDS). The study found that in order to save Jakarta from sinking, there should be a long-term solution. Based on this study, the late Jakarta Governor Fauzi Bowo was keen to contribute to the project. Even though the project was initiated by the central government, Fauzi was eager to contribute as the project location is in his territory. Fauzi then deployed a team to do independent study for designing this Giant Sea Wall and the opportunity to expand the city through reclamation project.

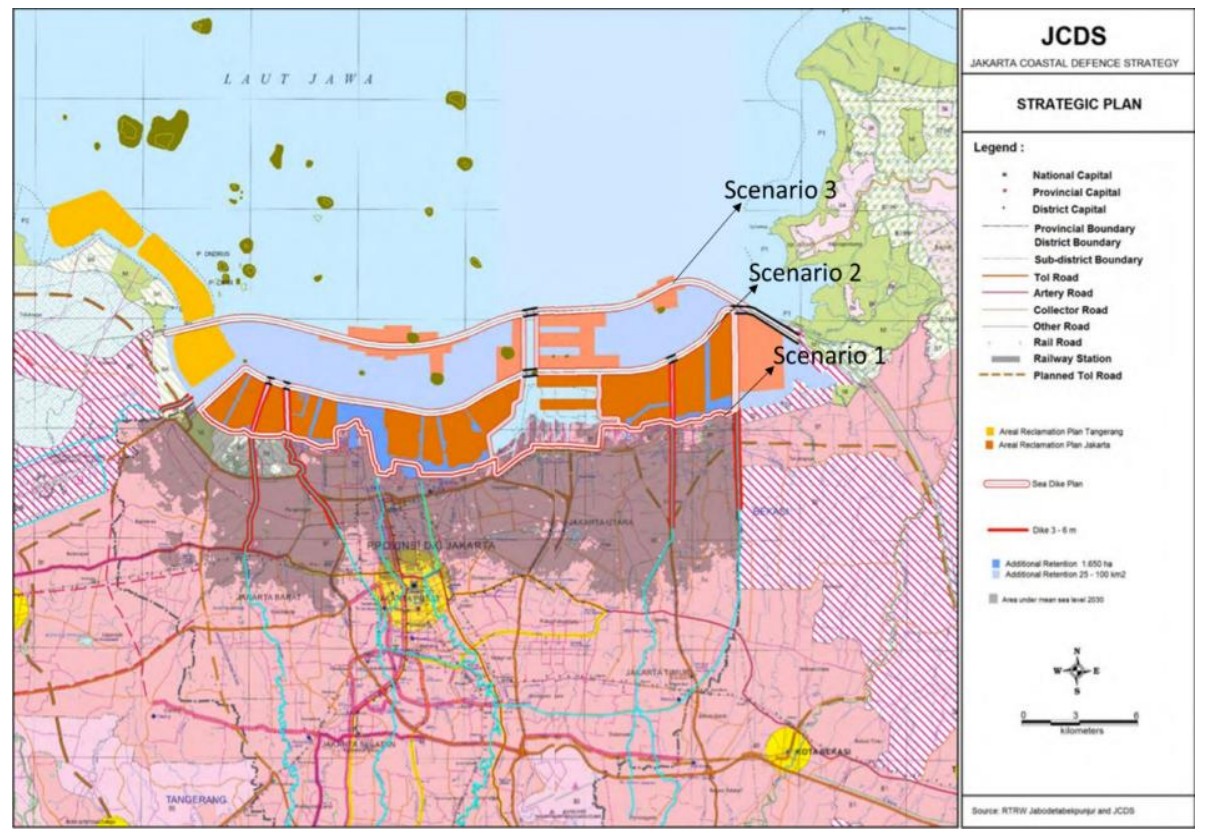

Fig. 1. The NCICD's proposed masterplan (Source: Public Works, Jakarta Coastal Defense Strategy: Agenda, 2011, page 113). 
While Jakarta Government was ready to provide long term solution for the city, the project was taken over by the Indonesian government. Continuing the bilateral relationship between the Indonesian and Dutch, the consortium issued Giant Sea Wall masterplan named National Capital Integrated Coastal Development (NCICD) for protecting Jakarta from sinking, the.

The team proposed three scenarios of sea walls integrated with the 17 reclamation lands established under Suharto era through presidential decree no 52, 13 July 1995 (Aziza, 2017). The first scenario is attached to the Jakarta bay to reduce the land subsidence, while the second scenario runs at the edge of the reclamation land. Meanwhile, the third scenario of Giant Sea Wall is on the deep sea water located $6 \mathrm{~km}$ away from the reclamation land. This third layer creates an estuary damn for the city and works as a protection from the sea flood. The masterplan will provide access to the current Tanjung Priok port (Fig. 1).

This plan was later adopted to Jakarta 2030 masterplan (Fig. 2). The sea wall spans from Tangerang to Bekasi. The masterplan indicates that Jakarta will have three layers of sea walls, with the outer layer functions as a dam and a wave breaker. The dam is going to be used as a water catchment from the 13 rivers running across the city. The water treatment plant is placed to ensure the quality of the water in the pond. There is no additional reclamation based on this master plan. Hence, Jakarta was designed as flood proof city.

By the end of 2011, Fauzi Bowo deployed a team to further develop this basic plan. The team consists of experts from various fields such as urban designer, civil engineer, dam, water management and IT experts.

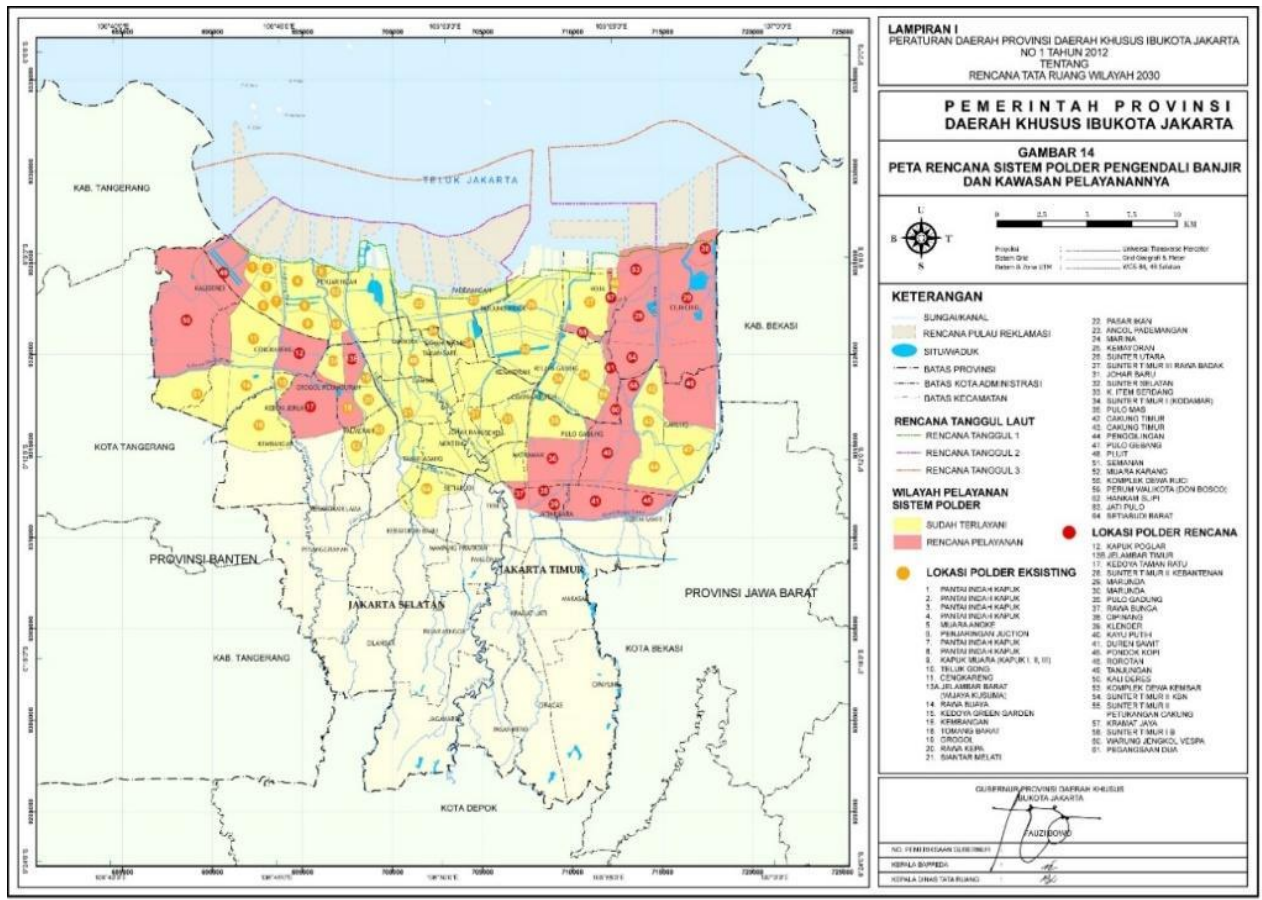

Fig. 2. Jakarta 2030 Masterplan (Source: Pemprov DKI, Perda DKI No 1 tahun 2012 tentang Rencana Tata Ruang Wilayah 2030). 
The team presented the new study and proposed new masterplan for the northern part of Jakarta. Jakarta is presented as a self-sustained city with abundance water, electricity and for future development. The new master plan allows the city to grow and gain its reputation as the beacon of the new emerging nation (Fig. 3).

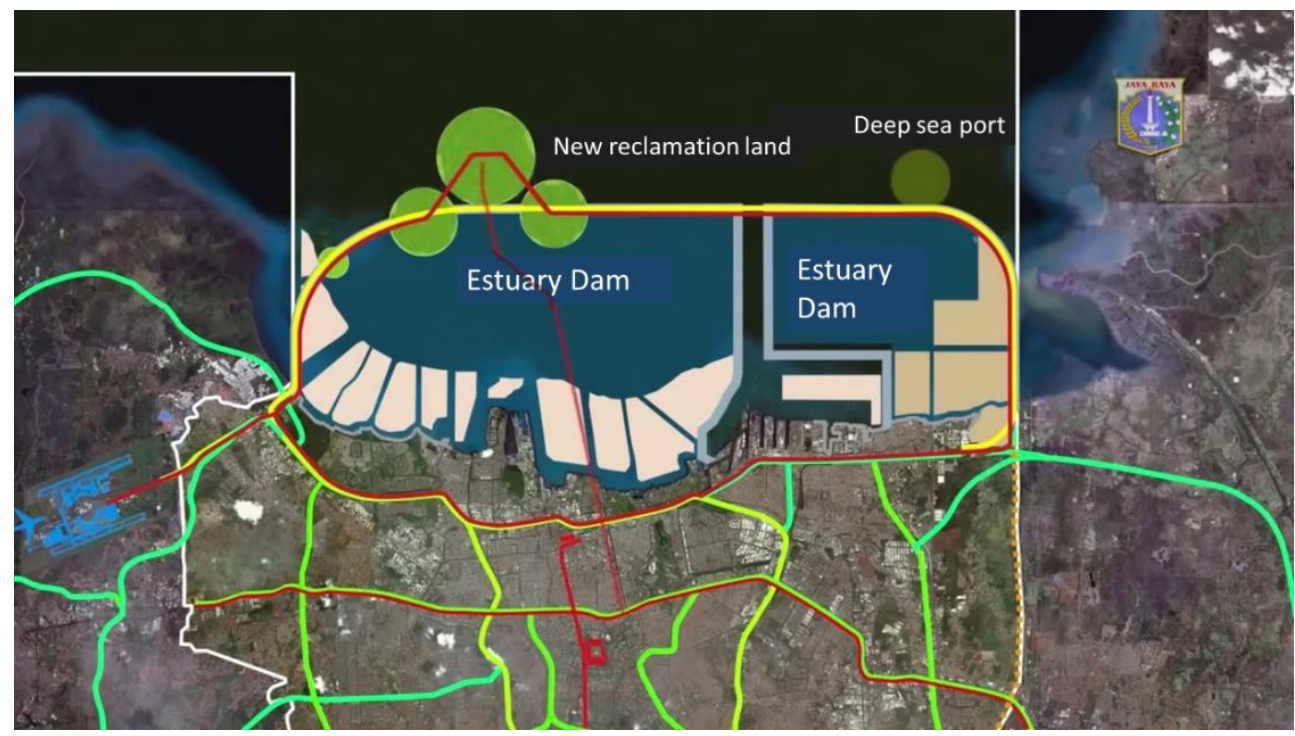

Fig. 3. Zoning of the Giant Sea Wall, New port and New Reclamation Area (Source: Pembangunan Jaya, 2013).

Based on this masterplan, the third layer of the sea wall spans only within the Jakarta area. This will help reducing the potential risks and political tension between three different provinces. The Giant Sea Wall also works as a toll road with the MRT line on the side and well connected to the existing city network.

The Giant Sea Wall has large lagoons working as an estuary dam. It buffers outflow from Jakarta's rivers especially during the rainy season where abundance amount of water was thrown out straight to the sea. To avoid the waste disposal, the water treatment and sanitation program would be implemented. This approach allows Jakarta to have water supply during the dry season. The estuary dam also enhances the lives of fisheries as the water has become clean and well treated. The idea of sustainability is heavily imposed

There are two parts of the reclamation lands for the new city proposed on this masterplan. One with the total area of 2000 Ha works as a new beacon for Jakarta. In later development, this area is divided into three islands displaying the future Jakarta as an economic driven and high-tech city (Pemprov DKI, 2012). Another smaller area was dedicated for traditional fisherman, allowing them to gain access to the deep sea.

Other reclamation land is dedicated for the deep-sea port as well as the Special Economic Zone (KEK). By far, the new Giant Sea Wall masterplan offers both protection to the city from sinking as well as opportunities to grow and compete with its Southeast Asian counterparts. The new Jakarta has its own supply of water, electricity, well integrated transportation network and deep-sea port. 
As this project was initiated from Bappenas, this initial masterplan by Fauzi's team was further developed by another consortium led by Witteven+Bos and Grontmij. Sub consultants joined in this project are Kuiper Compagnions, Deltares, Ecorys and Triple A. Financed by the Government of The Netherlands, the project is under the cooperation between two countries.

The team designed the Giant Sea Wall as a Great Garuda with its wings spread Tangerang to Bekasi (Fig. 4). However, unlike the previous design by Pembangunan Jaya, this masterplan took an Indonesian national symbol of Garuda bird. Garuda is seen as a nation savior, bold and brave figure which can bring prosperity for Indonesia (Kemenkoekuin \& National Capital Integrated Coastal Development, 2014).

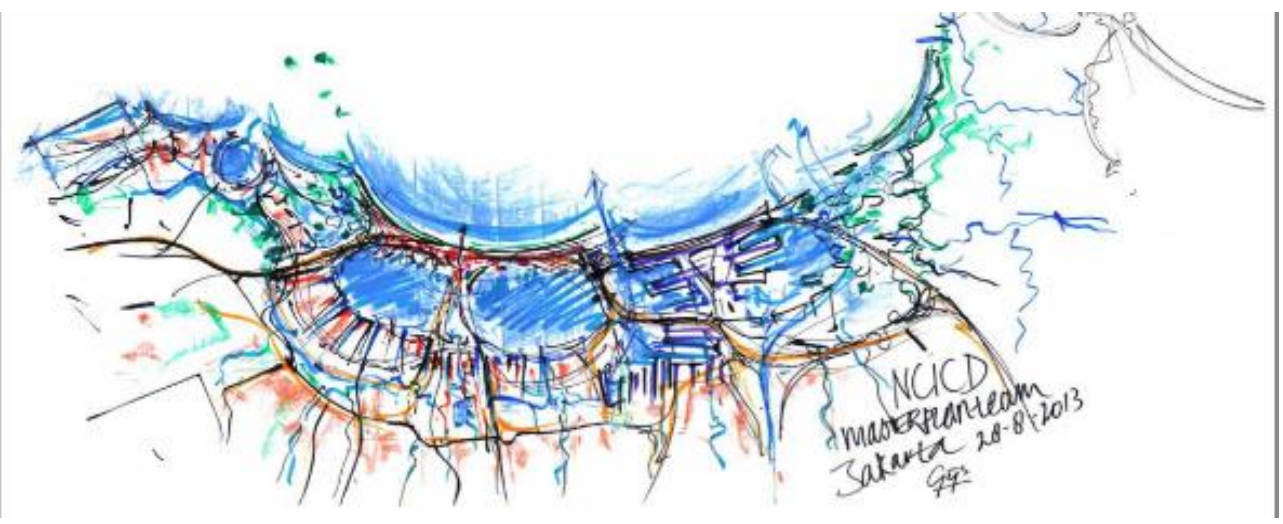

Fig. 4. Masterplan sketch by the Dutch Counterparts (Source: Kemenkoekuin \& National Capital Integrated Coastal Development, 2014).

Based on this design, the Garuda spans from Bekasi to the Tanjung Prior Port. The Port has its own extension to the deep sea integrated with the Giant Garuda. Reclamation land lays within the shape of Garuda and works as a new CBD. The Sea Wall functions as a toll road spanning 43 kilometers from Tangerang to Bekasi. On this outer sea wall there will be access to High Speed train which connects Jakarta to Cilegon and Banyuwangi. MRT line will have an access to the CBD and be integrated with the existing line. The symbol of Garuda as a national symbol will be the first image for foreigners and Indonesian expats when landing on the airport It is a welcoming gesture.

Most of these reclamation lands are for the high end mixed used urban development, offices and civic amenities such as school, hospitals and governmental functions (Kemenkoekuin \& National Capital Integrated Coastal Development, 2014). Later on the development of the masterplan, the reclamation land was furtherly added on the estuary dam area (Fig. 5).

Under the Ministry of the Economic Affairs, national Developing Planning Agency, Ministry of Public Works and the Special Capital Region of Jakarta, in corporation with the Netherlands in the field of water management, this Great Garuda quickly receives public attention. The Indonesian government quickly endorses the Dutch version of Giant Sea Wall design over the local consultant. The body and the head of Garuda serve as the central business district, where the tail is for the residential, mixed-used sport, leisure and entertainment. The wing is dedicated for the maritime communities where fishing port and fishermen live. Within this CBD, the new government buildings will be built. However, initially the Dutch counterparts designed the Garuda to span from the Tangerang to Bekasi. 
However, this plan was later being revised after series of discussions with the Fauzi Bowo's team. The Garuda was then resized due to the massive reclamation land that needs to be done.

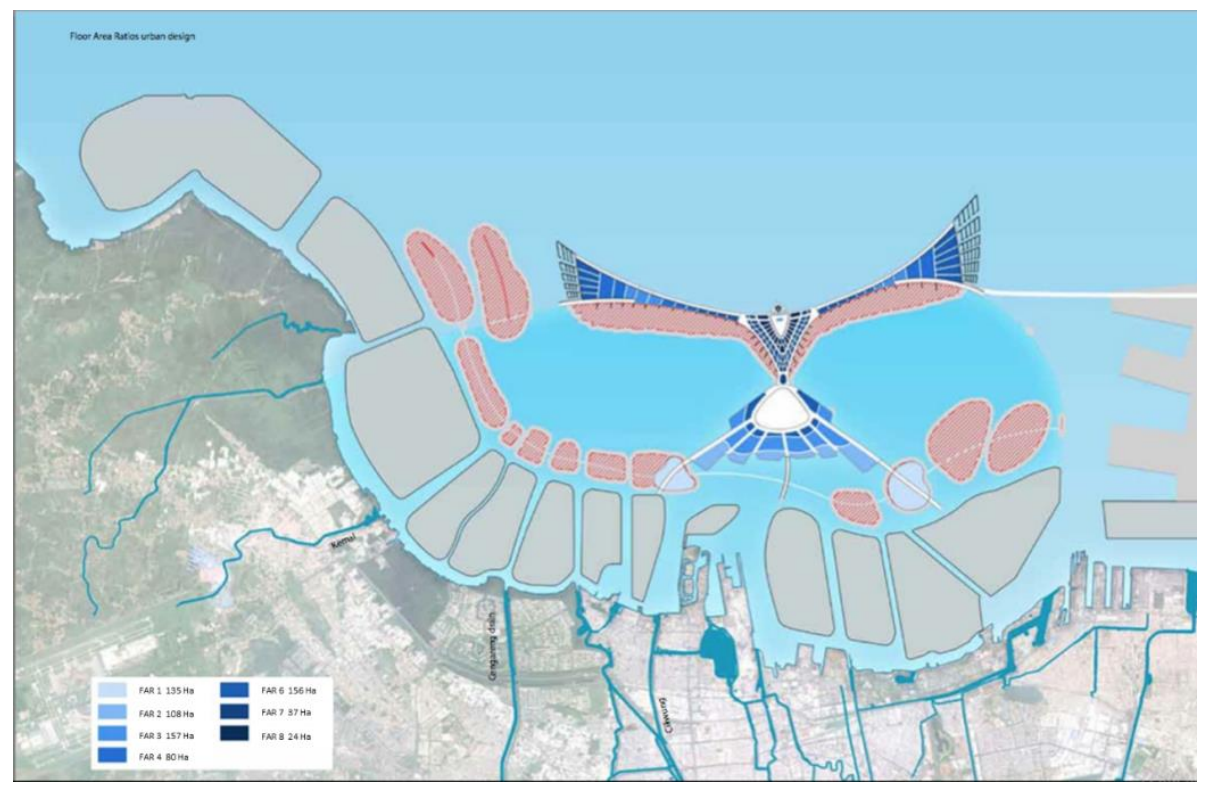

Fig. 5. Developed Masterplan (Source: Kemenkoekuin \& National Capital Integrated Coastal Development, 2014).

Regardless the controversy that the design of the new Jakarta was from the former colonizer, Jakarta is framed as a new Capitol complex where power insinuated in urban forms are displayed through the new Giant Sea Wall masterplan (Vale, 1992). The waterfront city is well connected to the inner train, MRT and road networks. Jakarta is presented as a new waterfront city, centre for business and leisure as well as politics. Jakarta is the new beacon for Southeast Asia.

This intense relationship between the former colonizer (Dutch) and the colonized (Indonesia) show a condition of post-coloniality (Maddison, 2012). The use of Garuda symbol can be seen as a way of winning the local's attention and approval. It is a sensitive and pride symbol for Indonesians.

By the end of 2017, SHAU an urban design firm submitted a masterplan for future Jakarta development in World Architecture Festival (WAFX) 2017. Out of 68 countries, SHAU's masterplan for Jakarta was selected as the winner of Smart Cities Prize. The prize is awarded to projects that overcome key challenges that cities need to address over the coming decade.

SHAU, based in Indonesia and Netherlands, proposed the new masterplan of Jakarta by integrating the Giant Sea Wall with the new 'Manhattan' island (Fig. 6). The new city is called Jakarta Jaya (Prabowo, 2017). Different from the Dutch version using the Garuda, this firm borrowed the idea of Manhattan as the new image for the Jakarta. SHAU maintains the outer sea wall and pushes it further outward. The new city is displayed as a symbol of prosperous nation with green and economically driven city. Different from most 
of cities in Indonesia, this new city uses grid system predominantly like European cities. This proposal was included in Dutch Prime Minister Rutte's bid book to Indonesian Government. Once again, Jakarta as the capital city is defined and framed through colonial eyes.

Ironically, the Jakarta government, although not happy for being dictated by the Dutch, is fond to the idea of having Giant Garuda or Manhattan as the new urban identity. The design is referred as arousing the nationalism and can function as a new urban identity for Indonesia. The city was designed to be a green, prosper, safe and economically driven. The dream of having a new city different from other cities in Indonesia but merely similar to other cities in Europe has become Indonesian complex paradox of the future dream city.

This condition reflects the concept of Capital and Capitol. Elite politics uses architectural forms to establish and legitimate a specific regime (Vale, 1992). As Vale (1992) points out, "government buildings are an attempt to build governments and to support specific regimes; they serve as symbols of the state" (Vale, 1992:3). These series of government buildings are called as capitol complex which are mostly located in the capital city. Apart from that, drawing boundaries is not simply determining the border but rather symbolizing the power by clearly identifying the territory (Gomis \& Turon).

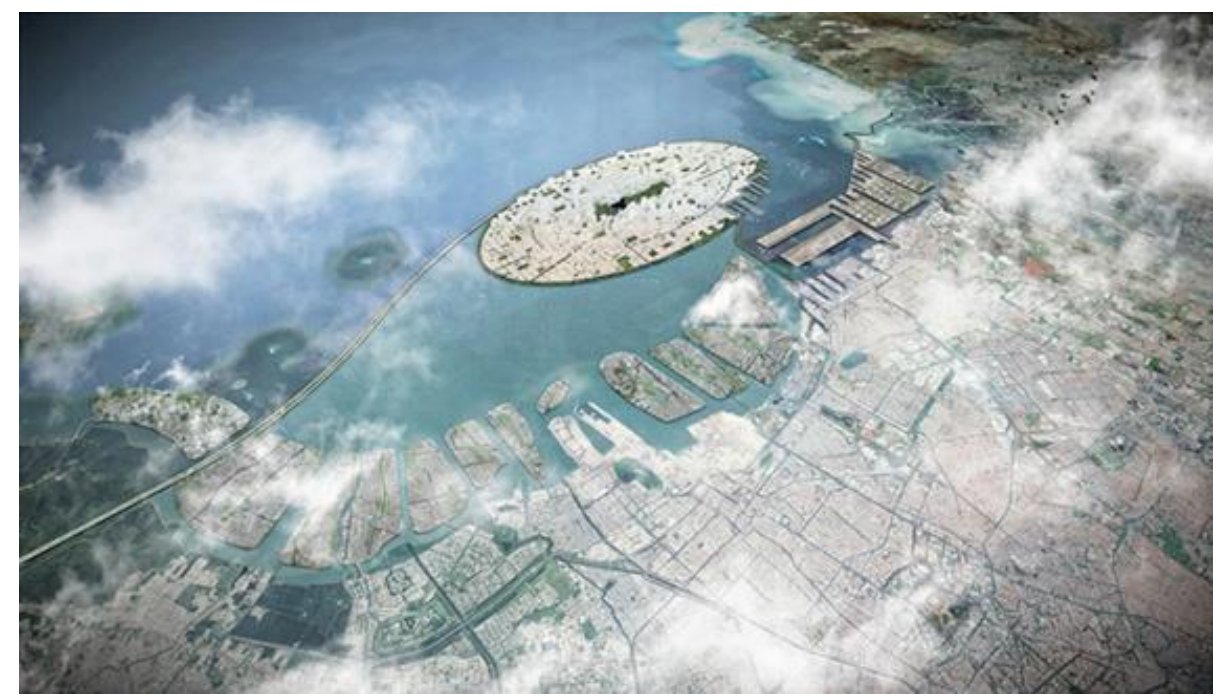

Fig. 6. Jakarta Jaya Masterplan by SHAU (Source: Leardi, 2017).

Each postcolonial ruler uses architecture and urban form to legitimate the regime and establish authority, displayed on a certain locus of power (Capitol). For the case of Giant Sea Wall, this city can be the new symbol for Jakarta which carry full of layered symbolism from Colonial Dutch and postcolonial Indonesian Presidents (see Kusno, 2000 and Permanasari, 2010). Through Giant Sea Wall masterplan project, the postcolonial government seizes the opportunity to legitimate its power and raise the nationalism even though it was framed by the colonial eyes. The practices of politics and urban forms collide and are displayed in urban forms shows the transformation of meaning and use of postcolonial city in Indonesia. 


\section{CONCLUSIONS}

This research analyzes the way in which the postcolonial government reconstructs the city in order to establish new urban identity. It interrogates dialectic relationship between the Dutch government and the Jakarta government approaches in defining new identity. It interrogates the extent to which the design of Giant Sea Wall can derive new identity for Jakarta and accommodate co-joint ideas both from the colonizer and the colonized. Through analyzing the design process of Giant Sea Wall and archival research, this project unravels layers of symbolism portrayed in the postcolonial city of Jakarta.

\section{REFERENCES}

Antara News (2013). Korban Jiwa Akibat Banjir Jakarta 19 orang [19 Victims Caused by Jakarta Flood] https://www.antaranews.com/berita/354079/korban-jiwa-akibat-banjir-jakarta-19orang / [Accessed March 2019].

Aziza, K. S. (2017). NCICD dan Reklamasi Teluk Jakarta Berbeda, Ini Penjelasan Bappenas [NCICD and Jakarta's Bay Reclamation Difference, Explanation from Bappenas] https://sains.kompas.com/read/2017/05/11/113300426/ncicd.dan.reklamasi.teluk.jakarta.ber beda.ini.penjelasan.bappenas. / [Accessed March 2019].

Chauduri, S. (2012), Indonesia rising: 2012 and beyond (Indonesia's potential and challenges to realizing it. Zur Startseite der AHK Indonesien website. http://indonesien.ahk.de/uploads/media/worldbank-indonesia_2012_and_beyond-2012-0416-Tempo_and_Ekonid_01.pdf [Accessed April 2017].

Fairclough, N. (2003), Analysing discourse: Textual analysis for social research, London and New York: Routledge. https://www.amazon.com/Analysing-Discourse-Textual-AnalysisResearch/dp/0415258936 [Accessed March 2019].

Gomis, J \& Turon C. (2017). Drawing the "Boundaries", the Start of an Urban Planning Project. Geographia Technica, 12(2) 73-81.

Kemenkoekuin \& National Capital Integrated Coastal Development (2014), Master Plan National Capital Integrated Coastal Development, Jakarta. Government of Indonesia and Government of Netherlands. https://www.bureauanl.nl/files/MP-final-NCICD-LR.pdf [Accessed March 2019].

Kusno, A. (2000), Architecture, Urban Space, and Political Cultures in Indonesia, London and New York: Routledge. https://www.amazon.com/Behind-Postcolonial-Architecture-PoliticalIndonesia/dp/0415236150 [Accessed March 2019].

Leardi, L.(2017). Visionary Masterplan Wins Smart City Prize at World Architecture Festival Arch Daily. https://www.archdaily.com/885037/visionary-master-plan-wins-smart-city-prize-atworld-architecture-festival [Accessed March 2019].

Maddison, S. (2012). Postcolonial guilt and national identity: historical injustice and the Australian settler state. Journal for the Study of Race, Nation and Culture 18(6) 695-709.

Neuman, L. W. (2006), Social Research Methods: Qualitative and Quantitative Approaches, USA: Pearson Education, https://www.amazon.com/Social-Research-Methods-QualitativeQuantitative/dp/0205615961 [Accessed March 2019].

Pembangunan Jaya \& ILWI. (2011). Kajian Awal Kepemrakarsaan: Pengembangan dan Pembangunan Tanggul Laut (Giant Sea Wall). PT Pembangunan Jaya. https://www.researchgate.net/publication/324558325 Report kajian Awal revitalisasi GS W [Accessed March 2019].

Pembangunan Jaya. (2013). Jakarta Revitalization Project. Jakarta: PT Pembangunan Jaya. https://www.researchgate.net/publication/324560043_Jakarta_Revitalization_Project [Accessed March 2019].

Pemprov DKI. (2012). Giant Sea Wall dan Waterfront City. Video Animasi. Jakarta: Bappeda. https://www.youtube.com/watch?v=0XVZjO6d8fI\&t=1s [Accessed March 2019]. 
Pemprov DKI. (2012). Perda DKI No 1 tahun 2012 Tentang Rencana Tata Ruang Wilayah 2030. Jakarta: Bappeda https://pelayanan.jakarta.go.id/download/regulasi/peraturan-daerah-nomor-1-tahun-2014tentang-rencana-detail-tata-ruang-dan-peraturan-zonasi.pdf [Accessed March 2019].

Permanasari, E. (2010). Constructing and Deconstructing the Nation: Sukarno's Monuments and Public Places in Jakarta, Germany: LAP Lambert Publishing. https://www.researchgate.net/publication/318877160_Constructing_and_Deconstructing_th e_Nation_The_Use_and_Meaning_of_Sukarno's_Monuments_and_Public_Places [Accessed April 2017].

Prabowo, D. (2017, November 3). "Jakarta Jaya" Konsep Reklamasi Terbaik WAFX Prize 2017. Kompas. $\quad$ https://properti.kompas.com/read/2017/11/03/225109021/jakarta-jaya-konsepreklamasi-terbaik-wafx-prize-2017?page=all [Accessed March 2019].

Public Works, M. o. (2011). Jakarta Coastal Strategy: ATLAS. Jakarta: Ministry of Public Works. https://www.scribd.com/doc/72755643/ATLAS-Jakarta-Coastal-Defense-Strategy [Accessed March 2019].

PwC. (2013). World in 2050: The BRICs and beyond: prospects, challenges and opportunities, Retrieved from $\mathrm{PwC}$ website https://www.pwc.kz/en/publications/new_publication_assets/world_in_2050_2013.pdf. [Accessed March 2019].

Sari, N., Kerugian akibat Macet Jakarta Rp 67 Triliun Per Tahun, Ini Kata Pemprov DKI [Jakarta Traffic Jam Caused IDR67 Billion Loss Every Year, Explanation from Jakarta Local Government] (2017, Oktober 6), Kompas, Retrieved from https://megapolitan.kompas.com/read/2017/10/06/17432751/kerugian-akibat-macet-jakartarp-67-triliun-per-tahun-ini-kata-pemprov [Accessed March 2019].

Syarif, H.(2013) Pertumbuhan Jalan Jakarta hanya 0.01 persen per tahun [Jakarta's Road Growth only $0.01 \%$ Every Year] Metronews.

https://metro.sindonews.com/read/804802/31/pertumbuhan-jalan-jakarta-hanya-001persen-per-tahun-1384245144 [Accessed March 2019].

Vale, L. (1992), Architecture, Power and National Identity. London: Yale University Press. https://yalepress.yale.edu/book/9780300049589/architecture-power-and-national-identity [Accessed March 2019]. 